\title{
THE HAUNTED CROSSROADS: LIBERIAN WARS AND TRANS-ATLANTIC TRAFFIC IN BLACK DIAMOND: THE YEARS THE LOCUSTS HAVE EATEN BY J. NICOLE BROOKS
}

\author{
Edyta LOREK-JEZIŃSKA (Nicolaus Copernicus University in Toruń) \\ ORCID: 0000-0002-5492-4255
}

\section{Introduction}

Writing about war raises many questions concerning representation, positioning and ethics. As Kate McLoughlin argues in her introduction to The Cambridge Companion to War Writing, "writing about war, and writing about that writing is fraught with possibilities of offending sensibilities [...] Discomfort is only to be expected." The reasons for that are multiple but one of them, as McLoughlin continues, is "larger-thanusual gap between representation and referent."2 War reporting interrogates the notions of objectivity, emotional attachment and positionality, throwing into doubt the belief in "impartial, dispassionate journalism" in the face of "brutal war or human calamity.", Writing about war in Africa or about Africa as such involves the risk of falling into clichéd images, pointedly listed in Binyavanga Wainaina's deeply ironic essay on

\footnotetext{
1 Kate McLoughlin, "Introduction," in The Cambridge Companion to War Writing (Cambridge: Cambridge University Press, 2009), 3.

${ }^{2}$ Ibid.

${ }^{3}$ See Martin Bell's concept of journalism of attachment discussed by Greg McLaughlin in "War reporting at the end of the twentieth century," in Formations: A $21^{\text {st }}$ Century Media Studies Textbooks, ed. Dan Fleming (Manchester: Manchester University Press, 2000), 115-116.
} 
"How to Write About Africa" (2005). ${ }^{4}$ Liberian Wars were also perceived as particularly problematic to account for because of the complexity of interests and power relations, resulting from re-colonialization, but also because of the emotional loading they entailed and ambiguous positions and roles they involved. ${ }^{5}$

Black Diamond: The Years the Locusts Have Eaten, written by J. Nicole Brooks American actress, playwright and director — and first staged in 2007 in Chicago, addresses many of these problems, exposing the controversies of representation and reporting, commenting on ambiguities of positioning and simultaneously provoking by confrontational and affective images and scenes. The play approaches the problems of representation of Liberian and American relations and the realities of the second Liberian civil war (1999-2003) from the perspective of a war reporter whose ambiguous relation to Liberia interferes with his journalist ethics and code of action.

Trying to present the complicated situation and history of Liberia, the shifting political alliances and conflicts and, most importantly, the colonial legacy of slave trade as well as displacement and recreation of settlement of American-Liberians in Africa, Black Diamond also asks questions about ethics, positioning vis-à-vis trauma and war and authorization to speak on behalf of others, problematized in scenes of hauntings and hallucinations.

Nicole Brooks' play develops around two main characters, one of which is modeled on the authentic figure of a woman soldier called Black Diamond, who lost her parents in war and was violently raped at the age of 13 by soldiers. In the second civil war she became a ruthless military leader herself in the armed forces of Women Artillery Commandos, whom she joined to avenge her parents and protect her daughter.

The second main character, whose perspective is central to this study, is a fictional character - Chogan Jim Fox, a reporter for BBC Africa, who goes through an identity crisis when faced with the atrocities of the war. This process is aided by his decision not to take his pills (for epilepsy) as a result of which he experiences psychotic states, in which he sees ancestral ghosts. The two characters meet because of the exclusive interview Fox is commissioned to conduct with Black Diamond. Both become connected by the figure of Jusu Masali, the one who saved Black Diamond after the rape in the past and hosts the journalist during the interview project. Masali, an artist and shaman producing traditional Liberian ritual masques, becomes a foster father to both of them. Jim comes to temporarily replace Masali's son, who is away in Europe, studying at the London School of Economics and planning, as Masali says, "to save us all from our economic disaster." The contact between Black Diamond and Jim Fox, difficult and problematic as it is, symbolically represents the dialogue between the local ethnic groups represented by the former and the newcomers/homecomers/invaders (Americo-Liberians) represented by the latter.

\section{Liberian Wars and Re-Colonization}

The second civil war on which the play focuses was directly caused by the internal conflict between the military regime of Charles Taylor, representing the American Liberians, and the alliance of what could be described as the descendants of native

\footnotetext{
4 Binyavanga Wainaina, "How to Write About Africa," Granta online edition 2019, https://granta.com/how-to-write-about-africa/.

${ }^{5}$ Gabriel I. H. Williams comments on his own deep emotional reactions to events he describes in his book Liberia: The Heart of Darkness (Victoria: Trafford Publishing, 2006), 36.

${ }^{6}$ J. Nicole Brooks, Black Diamond: The Years the Locusts Have Eaten (2007), in PostBlack Plays, eds. Harry J. Elam, Douglas A. Jones (London: Methuen Drama, 2012), 572.
} 
ethnic groups. Both sides committed similar atrocities, as Gabriel Williams describes in his book Liberia: The Heart of Darkness: "abductions, rape, forced recruitment, forced labor, torture, destruction of property, interference with privacy and family, and killings."7 The second war originated from the first civil war, in which Samuel K. Doe's regime was overthrown, but the conflict goes back to the origins of the country of Liberia, founded in 1822 by "freed men and women of color from America", supported by the philanthropic organization - the American Colonization Society. ${ }^{9}$

Americo-Liberians or Congos, as they are more often called, ${ }^{10}$ stood for the wealthy $5 \%$ of the population and controlled the political scene up to 1980 , when the group of soldiers, together with Sergeant Samuel Kanyon Doe, seized power in a bloody coup and introduced a military regime, supported lavishly by the US government (as Williams argues, mainly because of Doe's ostensive anti-Soviet sympathies), destroying the hopes of the poor majority connected with the first government representing the indigenous groups. ${ }^{11}$

With the attack of LURD on Monrovia and the second civil war the crimes committed by both sides of the conflict were intensified and also included the recruitment of child soldiers from the groups of displaced persons and refugee camps. ${ }^{12}$ In the war "[t]housands of children have been victims of killings, rape and sexual assault, abduction, torture, forced labor and displacement."13 According to the Human Rights Watch report, the children fighting with the military groups were "among the most affected by the war" as they both witnessed and perpetrated atrocities. ${ }^{14}$ The girls often served as wives to other soldiers being forced to sexual servitude, while boy soldiers were often drugged before combat, which made them "feel fearless" when fighting. ${ }^{15}$ As the report states, children who were fighting in the first war were easily recruited in the second civil war - some joined the forces to "avenge violations committed against their family members. Conversely, some children joined those same forces that committed abuses in their communities to offer protection to themselves and their families." ${ }^{\text {. }} 16$ The character of Black Diamond and other women fighters as well as child soldiers populating Brooks' play experience similar traumatic situations and motives.

The conflicts presented in the play by Nicole Brooks symptomise a number of problems, including the postcolonial relations between Liberian people and their land, the ties with and interference from the United States of America, the circulation of violence and domination, and most importantly, the ambiguous status of Liberians as both the colonizers and the colonized. In the Liberian context the trope of homecoming comes to represent simultaneously an act of invasion, as the former slaves' symbolic return involved also imposing the African American culture and domination on the indigenous

\footnotetext{
${ }^{7}$ Williams, Liberia: The Heart of Darkness, 185.

${ }^{8}$ Ibid, 22.

9 Among the members were Thomas Jefferson and James Monroe, whose name was celebrated in the name of the country's capital Monrovia.

${ }^{10}$ Original settlers from America and former slaves from the Congo Basin freed by the British and Americans. Williams, Liberia: The Heart of Darkness, 22.

${ }^{11}$ Ibid, 23.

${ }^{12}$ Ibid, 194.

13 Tony Tate and Human Rights Watch, How to Fight, How to Kill: Child Soldiers in Liberia, Human Rights Watch 16, no. 2 (2004): 1.

14 Ibid.

${ }^{15}$ Ibid, 2-3.

${ }^{16}$ Ibid, 9.
} 
people. As Williams argues, "[t]he American settlers built houses that echoed the architectural taste of Georgia, the Carolinas and Maryland. The constitution was written at Harvard Law School. Laws were codified in Cornell. For a long time, the only official currency was the American dollar." ${ }^{, 17}$ Taylor's regime further contributed to the increasing gap between the ruling class living in "luxury and comfort" and "the general population [who became] more severely afflicted from deprivation." ${ }^{, 18}$ In this way the conflict that is at the centre of Brooks' play is a consequence of the double displacement — originally from Africa to America as part of the slave trade and then from America to Africa, of freed slaves - both processes initiated and controlled by white people (first to gain cheap labour power and then to get rid of the threat of slave liberation). In the play the activities of the American Colonization Society are mocked in a satirical scene of the fictional debate between Martin Delaney (1812-1885) and Thomas Jefferson, in which the former, while naming the ACS as "a group of lewd, pigment-challenged, swag-bellied beasts!,", 19 accuses the latter of taking measures to "get rid of the dangerous population" and leading to what Jefferson in a slip of the tongue calls "the gradual extinction, eh hem - exodus, of the Negro from America." 20

\section{Displacement, Liminality and Haunting}

Displacement and spatial instability are reflected in the play's location. Although Black Diamond is set physically in Liberia, the setting is metaphorically described as "a crossroads where civil unrest meets the spirit world. Time and Place: 2003, Zamani (past) and Sasa (present). Location: Throughout Liberia, New York City, and all dimensions in between." ${ }^{21}$ Pervaded by instability and haunted by both invisible and visible ghosts, the setting of Brooks' play could be also described as the liminal space, which reflects the experience of Liberians during and between the civil wars, particularly affecting young people, who, as Mats Utas argues in his Sweet Battlefields: Youth and the Liberian Civil War, were drawn into "a subculture of liminality, characterized by abjection, resentment and rootlessness." 22 With the destruction of what could be described as normal social life during the civil wars and with the breakup of family and community, Liberians are suspended in destructive in-betweenness with little hope for transformation or improvement, which Jim Fox at the beginning of the play reports in a lengthy mock invitation:

Jim Fox: This is without a doubt one of the most dangerous places on earth. It's one of Africa's most ruthless civil wars. Ethnic cleansing, rape, torture, and crimes against humanity are committed on a daily basis. It's a war where soldiers get high on brownbrown; smear their faces with mud and makeup in the belief that 'Juju' West African magic will protect them from enemy bullets. Cross-dressing male combatants paint their fingernails bright red, wearing women's wigs, pantyhose, wedding gowns, even Donald Duck masks before committing some of the world's worst atrocities against their enemies. It's a war where child soldiers as young as seven years old carry teddy bears in one hand and AK47s in the other. Welcome to Liberia. ${ }^{23}$

\footnotetext{
${ }^{17}$ Williams, Liberia: The Heart of Darkness, 22.

${ }^{18}$ Ibid, 35.

${ }^{19}$ Brooks, Black Diamond, 617.

${ }^{20}$ Ibid, 616-617.

${ }^{21}$ Ibid, 548.

22 Mats Utas, Sweet Battlefields: Youth and the Liberian Civil War (Uppsala: Uppsala University Dissertations in Cultural Anthropology, 2003), abstract.

${ }^{23}$ Brooks, Black Diamond, 562.
} 
Although effectively describing the dangerous liminality of war and its sinister carnivalesque excesses, the description primarily serves as a parody of the sensational journalistic jargon and its reliance on cultural clichés. It illustrates Jim's initial attitude of sarcastic indifference to the reported events and, therefore, prepares the ground for his later transformation.

Liminality also stands for displacement and exile, both intra- and transnational, expressed in the concepts of haunting and being haunted by traditional African gods and spirits, whose influence extends beyond national and continental borders. Jim partly self-consciously imposes on himself the condition of being a stranger, through which he tries to understand the experience of displacement associated with the transatlantic black diaspora. Getting ready for the contact with the new/old culture and the confrontation with the reality of war is a self-destructive and risky process, as in hallucinations Jim seems to fall into madness and lose his sense of identity and stability. Opening up to the strange culture, which is at the same time his own heritage, involves internalizing the alien part of himself and rejecting the stable identity protected by his medication. Like in Kristeva's description of the foreigner's condition, Jim "confront[s] the foreigner whom [he] reject[s] and with whom [he] identifies," losing his "boundaries" and his "composure," feeling "'lost, ' 'indistinct,' 'hazy".,24

Still another aspect of liminality is reflected in the mixture of cultures through which characters communicate, drawn from both American and African sources. In such liminal space nothing is stable, characters change and evolve as they are multicast in performance (except for the two major characters, Jim and Black Diamond). Inbetweenness and heterogeneity are reflected in the play's multiplicity of forms, structures and cultural references, from traditional African magic beliefs, to American politics to graffiti and hip-hop culture. Thus in one scene the audience is confronted with ancestral spirits and giant spiders representing African beliefs, while in the other ironically with a character modelled on and inspired by Ripley from James Cameron's Aliens. Liberian female soldiers sing Michael Jackson's "Liberian Girl" and imitate Mick Jagger, as well as perform the songs of American rap musicians, adding their own lyrics, only to join in call and response chanting on another occasion. The scenes happening in Liberia are interrupted by vaudeville-like sketches mockingly depicting the history of Liberia and American-Liberian relations, featuring the character of American Dummy (a ventriloquist's doll) and many American politicians in what seems to be an American TV satirical show. As Harry Elam and Douglas Jones in their introduction to Post-Black Plays assert, "[t]he contrasts and ambiguities in style underscore the contradictory cultural politics at play within this catastrophic African struggle. By depicting rebel soldiers that associate their own brutality and swagger with the urban cool of African American hip hop, Brooks' play showcases the complications and ambiguities of black cultural traffic, the flow, and importantly, the friction of black imagery."25

\section{War Journalism: Attachment and Vulnerability}

Jim Fox, the journalist, is confused by the mixture of estrangement and belonging that he comes to experience. At the beginning of the play we see him at the moment of crisis, where his professional code interferes with his identification with the Liberian

\footnotetext{
${ }^{24}$ Julia Kristeva, Strangers to Ourselves (New York: Columbia University Press, 1991), 187.

${ }^{25}$ Harry Elam and Douglas Jones, "Introduction," in Post-Black Plays (London: Methuen Drama, 2012), xxxii.
} 
people. He starts to claim to have greater right to talk about Liberia ("Let me be clear about something, these are my people..."26) than his Irish companion solely on the basis of skin colour, which is criticized by the latter: "You that think some 'black unity' passport is going to get you inside this beast?"27. This proximity characteristic of 'journalism of attachment' has, as Kate McLoughlin argues in a general context of war journalism, "awkward ethico-aesthetic consequences," 28 which Mick Hume associates with boosting the journalists' self-importance by turning them into "saintly crusaders abroad" and functioning as a "twisted sort of therapy." ${ }^{29}$ Yet in Jim's case this initial engagement in journalism of attachment leads to far-reaching consequences, affecting his attitude and ability to understand what he is trying to report. His rejection of detachment leads him towards journalism that in Martin Bell's words "cares as well as knows" and "is aware of the moral grounds on which it operates." 30 Jim's decision not to take prescribed pills for epilepsy metaphorically represents his readiness to become vulnerable, to experience the events rather than objectively report them. His vulnerability - shedding the medical shield that keeps him efficient and eloquent, opens him up for the spiritual experience in hallucinations and hauntings. This new state of mind prevents him from fulfilling his role and reporting the events from what could be seen as an objective distance, as he struggles to film the material to be shown in the news. His eloquent beginning: "It's the only African country with the distinction of the label, "made in America" soon deteriorates, demonstrating his "impaired comprehension and word difficulty," 31 as the stage directions suggest. Jim also seems to suffer physically and his bodily reaction testifies to the trauma of war that he vicariously experiences. In that respect Jim resembles the character of Ian in Sarah Kane's play Blasted, who similarly - albeit more drastically — becomes the medium of testimony, ${ }^{32}$ and it is only through that experience that he manages to understand what it means to report death and suffering. Jim's vicarious trauma ${ }^{33}$ concerns both the experience of the Liberian War but also the whole legacy of slavery and colonization.

Criticizing the media conglomerates for their omission, fabrication and underreporting of African affairs, Jim accuses them of lying and manipulating people. But when he tries to present the "truth," his report transforms into a grotesque satirical political show, exposing the prejudice, indifference and mercenary attitudes of Americans to Liberian people, demonstrated in a series of mock-quotations from US presidents and other political and historical figures. The hallucinatory show presents a nightmarish version of Liberian history, focusing on the country's relations with America. Offensive and provocative as they are, the show scenes expose fears, ignorance and racism of American authorities and the corruption and violence of Liberian politicians. What is

${ }^{26}$ Brooks, Black Diamond, 556.

${ }^{27}$ Ibid, 557.

${ }^{28}$ Kate McLoughlin, "War in Print Journalism," in The Cambridge Companion to War Writing (Cambridge: Cambridge University Press, 2009), 52.

${ }^{29}$ Mick Hume qtd. in McLoughlin "War in Print Journalism," 52.

${ }^{30}$ Martin Bell qtd. in Greg McLaughlin, "War reporting at the end of the twentieth century," in Formations: A $21^{\text {st }}$ Century Media Studies Textbooks, ed. Dan Fleming (Manchester: Manchester University Press, 2000), 115.

${ }^{31}$ Brooks, Black Diamond, 554.

32 Peter Buse, Drama + Theory: Critical Approaches to Modern British Drama (Manchester: Manchester University Press, 2001), 182.

${ }^{33}$ Ann E. Kaplan, Trauma Culture: The Politics of Terror and Loss in Media and Literature (New Brunswick: Rutgers University Press, 2005), 21. 
important for this argument, they also place the main character in the position of a victim, who suffers racist abuse and is identified as a slave in the historical mock-reenactments of speeches and debates from which the idea of the country populated by freed slaves emerged. These hallucinations exhaust Jim psychically, but it is through them that he becomes aware of the complexity of his own relation to Liberia and - because of his mental suffering - becomes the medium of testimony.

\section{Hauntings}

Jim's metaphorical and physical homecoming and the confusion of this process echo the problematic nature of re-colonization of Africa by African Americans. Jim himself becomes the figure of haunting, as a revenant who follows the route of African American backward colonization. When Jim explains to Masali that is it his first visit to Liberia, the shaman replies: "A spirit never forgets the road home!,"34 by which he implies that on the spiritual level (with the double implication of this word) his first visit is a form of return. If we connect this aspect with Jacques Derrida's conviction that "the spirit is always a revenant. One cannot control its comings and goings because it begins by coming back," 35 we might think of Jim's arrival in Liberia as re-enactment of both the original displacement of African people and the legacy of their return. With the concepts of belatedness ${ }^{36}$ and transgenerational trauma, ${ }^{37} \mathrm{Jim}$ comes to embody in a literal and metaphorical sense - the trauma of departure and loss as well as the violence of homecoming, expressed in hallucinations and spiritual encounters. Because of belatedness, the trauma he lives through might be in fact a re-enactment of the earlier events experienced by him directly or alternatively, it could be interpreted as cultural or transgenerational trauma inherited by him as a descendant of former slaves.

The first encounter with spirits happens when Jim cannot accept that - as a reporter - he should report on death but not bury the dead. In his first hallucination he sees the ancestral gods giving the dead body a proper ritualistic burial. In Masali's house he is repetitively haunted by the spirits represented by the host's ritualistic masques and giant spiders. At the moment of Masali's death experienced as hallucination, he comes to deny his affinity to Liberian people, saying "I have to leave ... I won't do this. Please let me out. [...] I don't belong here! I'm not one of them! I'm not one of you!," to which the American Dummy character replies "Now why should you get to leave, if they can't?". ${ }^{38}$ However, after Masali's real death Jim does leave and takes with him to America Masali's blood-stained shirt as well as his masques, spirits and spiders and lets them out of his suitcase, allowing them to stay with him because, as Jim's girlfriend puts it: "Liberia ain't done with its prodigal son." 39

\footnotetext{
${ }^{34}$ Brooks, Black Diamond, 572.

${ }^{35}$ Jacques Derrida, Specters of Marx: The State of the Debt, the Work of Mourning and the New International (New York, London: Routledge, 2006), 11.

${ }^{36}$ Sigmund Freud's concept of belatedness refers to the situation in which "the patient does not remember anything of what he has forgotten and repressed, but acts it out" as if for the first time; Sigmund Freud, "Remembering, Repeating and Working-through: Further Recommendations on the Technique of Psycho-analysis II," (1914) in The Standard Edition of the Complete Psychological Works of Sigmund Freud, vol. xii (London: Hogarth Press, 1950), 150.

${ }^{37}$ Nicolas Abraham, "Notes on the Phantom: A Complement to Freud's Metapsychology," in The Shell and the Kernel: Renewals of Psychoanalysis (Chicago: University of Chicago Press, 1994), 175-176.

${ }^{38}$ Brooks, Black Diamond, 622.

${ }^{39}$ Ibid, 632.
} 
Although from another perspective it could be classified as an instance of cultural appropriation, it seems that wherever Jim settles he brings a suitcase full of ghosts who come to define his home as homely paradoxically through its very unhomeliness/ unheimlich associated with ghosts. ${ }^{40}$ Just like Americans evacuated in 1990, "leaving Liberians to fend for themselves," ${ }^{41}$ he is allowed to leave but not to forget Liberia. He compares the memory of what happened to him to the mass graves one has to step over in order to get to Liberia's beautiful beaches. In Ghostly Matters, Avery Gordon stresses the influence of haunting and spectres on time and memory: "Haunting raises spectres, and it alters the experience of being in time, the way we separate the past, the present, and the future." ${ }^{22}$ In Jim's experience they coexist - simultaneously inhabit the private and public space, his inherited past, lived presence and anticipated future.

The other significant ghostly apparitions that visit Jim in his hallucinations and memories are child soldiers. "As young as seven years old carry[ing] teddy bears in one hand and AK47 in the other," 43 child soldiers are presented in the play as ghosts or spirits, returning in memory or flashback scenes. Their deceptive innocence and assumed victimhood evoke compassion in Jim and Tristan (Irish cameraman), prompting them to action, in which they try to save one of the boys (Olivier). However, their intervention only exacerbates violence as the boy is killed, punished for talking to strangers, while the journalists are wounded. This incident raises questions of war reporter's ethical code, of, as Tristan puts it, being "on assignment, not a rescue mission." 44 The second boy - Jacob - appears in the story of one of the women soldiers, called Born to Suffer. She tries to explain why she became a rebel fighter, describing the moment of her son being recruited presumably by Taylor's soldiers.

Having met parents with a child on the way home from church, the drunk soldiers try to persuade the son to join them and become "their little brother," praising the advantages of a warrior's life. When the father protests, they teach the boy how to hold a gun and, pointing at the father, they force the boy to pull the trigger. When the son sends several bullets into the father's body, the soldiers mockingly praise him: "He's the real killer boy, yeah!". ${ }^{45}$ In his hallucinations Jim, feeling guilty about Olivier's death, imagines himself as the boys' executioner, with his hand holding a gun, guided by Black Diamond. In his epileptic seizures he re-experiences the futility of intervention. Black Diamond tries to persuade him not to think of the boys. She repeats that at the time when they became child soldiers they were already dead and could not be saved; once a child becomes a victim and turns into a soldier, there is no return and no end to violence. Jim's struggle with a sense of guilt and responsibility on a more general level represents the problematic nature of political aid and intervention, which - when misunderstood and miscalculated - leads to further suffering and violence. What is also at stake here is the European (mis)interpretation of family relationships in Liberia. What might be seen as the disintegration of the family during the civil war and

${ }^{40}$ In his discussion of The Shining, Mark Fisher commented on the implications of "home is where the haunt is," referring to the affinity between home, homeliness and haunting as discussed in Freud's essay on the uncanny. See Mark Fisher, Ghosts of My Life: Writings on Depression, Hauntology, and Lost Futures (Winchester: Zero Books, 2014).

${ }^{41}$ Brooks, Black Diamond, 561.

${ }^{42}$ Avery F. Gordon, Ghostly Matters: Haunting and the Sociological Imagination (Minneapolis: University of Minnesota Press, 2008), xvi.

${ }^{43}$ Brooks, Black Diamond, 562.

${ }^{44}$ Ibid, 556.

${ }^{45}$ Ibid, 608. 
destabilization connected with displacement and abandonment, to some extent is the result of the practice of child fostering and extended family and community's responsibility for childcare in West Africa, including Liberia. ${ }^{46}$ This seems to account for the strong feelings of allegiance and solidarity within the ethnic group, explains the ease with which the characters refer to each other as brothers and sisters, fathers and daughters or sons, even though there is no blood relation between them. It also stands behind Masali's adoption and foster parenting to Jim. While focusing on the traumatic consequences of soldiering for children, the study on "The Psychological Impact of Child Soldiering" also admits that one of the reasons why children were recruited in the twentieth century was that "becoming a fighter may be an attractive possibility for children and adolescents facing poverty, starvation, unemployment, and ethnic or political persecution ... [and] they may be more willing to fight for honour or duty, for revenge, or for protection from violence." $" 47$ The scenes featuring child soldiers illustrate the naivety of humanitarian action and futility of good intentions, raising also questions of the journalists' code of actions and responsibilities involved in the act of witnessing and bearing witness to atrocities of war and trauma.

\section{Conclusion}

Black Diamond ends with a highly symbolic and ritualistic scene of opening Pandora's box, with stage directions marking a gap, a hiatus, that probably stands for hope symbolised by "beautiful light," 48 (re)uniting the characters of Jim Fox and Black Diamond, representing American Liberians and native Africans, respectively. This symbolic ending, ostentatiously unrealistic but hopeful at the same time, can be seen as a final commentary on the necessity for action and cooperation, but also a call for the journalism of attachment and testimony, which affects its subject matter but also transforms the reporters themselves. The acts and metaphors of haunting in this case lead to the processes of internalization described by Terry Castle, in which "it becomes difficult to distinguish between perception and possession, hard to know if any perceived other is in fact other, or is merely a projection of the haunted self." 49 In that respect, Black Diamond presents the process of internalizing the ghosts and making them part of identity by refusing to identify them as symptoms of illness.

Capitalizing on the contradiction and affinity between home / homeliness and haunting / unheimlich, Nicole Brooks presents through the character of Jim the sense of familiarity and domesticity as well as belonging in the African culture and beliefs combined with the spectral uncanniness and estrangement, going back in time to the pre-colonial period. This sense of inbetweenness and the uncanny familiarity of the other and strangeness of the same are bound to stay with him wherever he is. In that Jim's condition represents the split identities of Liberians - torn apart by the military conflict, but also torn between and accommodating both home and exile. Jim's status of

\footnotetext{
${ }^{46}$ Uche C. Isiugo-Abanihe, "Child Fosterage in West Africa," Population and Development Review 11, no. 1 (1985): 56.

${ }^{47}$ Elisabeth Schauer and Thomas Elbert, "The Psychological Impact of Child Soldiering," in Trauma Rehabilitation After War and Conflict (New York: Springer Verlag, 2010), 316.

${ }^{48}$ Brooks, Black Diamond, 635.

49 Renée L. Bergland, "From Indian Ghosts and American Subjects," in The Spectralities Reader: Ghosts and Haunting in Contemporary Cultural Theory (London: Bloomsbury, 2013), 377-378.
} 
a revenant and the one that is haunted embodies the sense of displacement and instability inherited from earlier generations of African Americans returning home.

Haunting itself, as Avery Gordon argues, is "one way in which abusive systems of power make themselves known and impact felt," registering "the harm inflicted or the loss sustained by social violence done in the past or in the present." ${ }^{, 50}$ Haunting in Black Diamond, experienced both by indigenous people and the "newcomers," serves as the testimony to both past and present injustice and violence, going back to the times of slavery, re-colonisation of Africa and the local conflicts, in which at some point both sides become guilty of comparable brutality and inhumanity. But haunting, in contrast to trauma, as Gordon continues, "is distinctive for producing a something-to-be-done," when the chaos and disorder, "disturbed feelings," things and people that are supposed to be invisible "show up without any sign of leaving." realized both through internalization of haunting and its external persistence, enforcing reaction and action, which, although fraught with mistakes and miscalculations, can lead to awareness and change.

\section{BIBLIOGRAPHY}

Abraham, Nicolas. "Notes on the Phantom: A Complement to Freud's Metapsychology." In The Shell and the Kernel: Renewals of Psychoanalysis, ed. and transl. Nicholas T. Rand, 171176. Chicago: University of Chicago Press, 1994.

Bergland, Renée L. "From Indian Ghosts and American Subjects." In The Spectralities Reader: Ghosts and Haunting in Contemporary Cultural Theory, eds. María del Pilar Blanco and Esther Peeren, 371-392. London: Bloomsbury, 2013.

Brooks, J. Nicole. Black Diamond: The Years the Locusts Have Eaten. In Post-Black Plays, eds. Harry J. Elam, Jr and Douglas A. Jones, Jr, 545-635. London: Methuen Drama, 2012.

Buse, Peter. Drama + Theory: Critical Approaches to Modern British Drama. Manchester: Manchester University Press, 2001.

Derrida, Jacques. Specters of Marx: The State of the Debt, the Work of Mourning and the New International. New York, London: Routledge, 2006.

Elam, Harry, J. and Douglas A. Jones. "Introduction.” In Post-Black Plays, eds. Harry J. Elam, Jr and Douglas A. Jones, Jr, ix-xxxv. London: Methuen Drama, 2012.

Freud, Sigmund. "Remembering, Repeating and Working-through: Further Recommendations on the Technique of Psycho-analysis II" (1914). In The Standard Edition of the Complete Psychological Works of Sigmund Freud, vol. xii, ed. James Strachey, 147- 156. London: Hogarth Press, 1950.

Fisher, Mark. Ghosts of My Life: Writings on Depression, Hauntology, and Lost Futures. Winchester: Zero Books, 2014.

Gordon, Avery F. Ghostly Matters: Haunting and the Sociological Imagination. Minneapolis: University of Minnesota Press, 2008.

Isiugo-Abanihe, Uche C. "Child Fosterage in West Africa." Population and Development Review 11, no. 1 (1985): 53-73.

Kaplan, Ann E. Trauma Culture: The Politics of Terror and Loss in Media and Literature. New Brunswick: Rutgers University Press, 2005.

Kristeva, Julia. Strangers to Ourselves. New York: Columbia University Press, 1991.

McLaughlin, Greg. "War Reporting at the End of the Twentieth Century." In Formations: A $21^{\text {st }}$ Century Media Studies Textbooks, ed. Dan Fleming, 112-116. Manchester: Manchester University Press, 2000.

McLoughlin, Kate. "Introduction." In The Cambridge Companion to War Writing, ed. Kate McLoughlin, 1-3. Cambridge: Cambridge University Press, 2009.

\footnotetext{
${ }^{50}$ Gordon, Ghostly Matters, xvi.

${ }^{51}$ Ibid.
} 
McLoughlin, Kate. "War in Print Journalism." In The Cambridge Companion to War Writing, ed. Kate McLoughlin, 47-57. Cambridge: Cambridge University Press, 2009.

Schauer, Elisabeth, and Thomas Elbert. "The Psychological Impact of Child Soldiering." In Trauma Rehabilitation After War and Conflict, ed. Erin Martz, 311-360. New York: Springer Verlag, 2010.

Tate, Tony, and Human Rights Watch. "How to Fight, How to Kill: Child Soldiers in Liberia." Human Rights Watch 16, no. 2 (2004): 1-43.

Utas, Mats. Sweet Battlefields: Youth and the Liberian Civil War. Uppsala: Uppsala University Dissertations in Cultural Anthropology, 2003.

Wainaina, Binyavanga. "How to Write About Africa." Granta online edition (2019) https://granta.com/how-to-write-about-africa/.

Williams, Gabriel I. H. Liberia: The Heart of Darkness. Victoria: Trafford Publishing, 2006.

THE HAUNTED CROSSROADS: LIBERIAN WARS AND TRANS-ATLANTIC TRAFFIC
IN BLACK DIAMOND: THE YEARS THE LOCUSTS HAVE EATEN BY J. NICOLE BROOKS

The article examines conflicted discourses and representations of the Liberian civil war and Liberian identities in the 2007 play Black Diamond by an American playwright and actress, J. Nicole Brooks. Its main objective is to investigate how the play endeavours to confront the complicated situation and history of Liberia, focusing on the colonial legacy of slave trade, displacement and recreation of settlement of American-Liberians in Africa, as well as the shifting political alliances and conflicts Liberia experiences nowadays. The play's complexities and contradictions reflect the postcolonial relations between Liberian people and their land and expose the ties with and interference from the United States of America. The play discusses the ambiguous status of Liberians as both the colonizers and the colonized and shows the circulation of violence and domination, transforming homecoming into invasion. Black Diamond also asks questions about the ethics of representation, positioning vis-à-vis trauma and war and authorization to speak on behalf of others, problematized in scenes of hallucinations and hauntings.

KEY WORDS: Liberian wars, haunting, liminality, colonialism, journalism of attachment

\section{NAWIEDZONE SKRZYŻOWANIA: WOJNA DOMOWA W LIBERII I HANDEL TRANSATLANTYCKI W CZARNYM DIAMENCIE J. NICOLE BROOKS}

Artykuł poświęcony jest problemowi reprezentacji wojny domowej w Liberii i dyskusji na temat tożsamości Liberyjczyków podjętej w sztuce dramatycznej pt. Czarny Diament z 2007 roku, autorstwa amerykańskiej dramatopisarki i aktorki, J. Nicole Brooks. Głównym celem artykułu jest zbadanie strategii reprezentacji i dyskursów wykorzystanych w sztuce dla odzwierciedlenia złożonej sytuacji i historii kraju, poczynając od dziedzictwa kolonializmu i handlu niewolnikami, poprzez problemy ponownego osadnictwa amerykańskich niewolników w Afryce, aż po zmieniające się układy polityczne w czasach obecnych. Złożona struktura sztuki, wraz z jej wewnętrznymi sprzecznościami, obrazuje skomplikowany stosunek Liberyjczyków do swojego kraju, na który dodatkowo silny wpływ wywierają relacje ze Stanami Zjednoczonymi. Dramat Brooks wskazuje na podwójny status Liberyjczyków jako zarówno kolonizatorów, jak i skolonizowanych, ukazując mechanizmy przemocy i dominacji, w których powrót do domu po latach wygnania wydaje się jednocześnie aktem inwazji. Sztuka Nicole Brooks stawia też pytania o etykę reprezentacji, kwestie umiejscowienia podmiotu w stosunku do wydarzeń traumatycznych i wojny, a także porusza problem autoryzacji świadectwa wydarzeń i wypowiadania się w imieniu innych, ukazany w scenach halucynacji i nawiedzenia.

SŁOWA KLUCZOWE: wojny domowe w Liberii, nawiedzenie, liminalność, kolonializm, dziennikarstwo zaangażowane 